\title{
THE EFFECT IN THE WASTEWATER TREATMENT AT SOYBEAN CURD OF CONTACT TIME MODIFICATION OF ARTIFICIAL WETLAND USING SSF BY USING Schoenoplectus corymbosus TO IMPROVE WATER QUALITY
}

\author{
Arif Mahdiana1, Asrul Sahri Siregar ${ }^{1}$, Sonny Januar C, Norman Arie Prayogo ${ }^{1}$, \\ ${ }^{1}$ Program Studi Manajemen Sumberdaya Perairan, Fakultas Perikanan dan Ilmu Kelautan, Universitas \\ Jenderal Soedirman
}

\begin{abstract}
Soybean curd industrial is rapidly growing industry. Characteristic of effluent from soybean curd industrial may contains a lot of organic materials and suspended solids that give negative impact to water. One of the soybean curd industry pollution prevention is a modification of artificial wetlands with sub surface flow system using recirculation by $S$. corymbosus plant to reduce the value of BOD, TSS and nitrate in soybean curd wastewater. Early of research procedure is prepare wetland construction consist of 8 part box container with a capacity of 75 $\mathrm{L}$, then filled in the basic medium gravel $5 \mathrm{~cm}$, clay $10 \mathrm{~cm}$, and then planted a $S$. corymbosus by 30 pieces/construction, then drained soybean curd waste that has been diluted through the recirculation pipe for 16 days in the land of green house plant physiology. The result of optimal decline BOD occured on day $12^{\text {th }}$ ie 99,7 , TSS decline value optimal ie $89,3 \%$ on day $12^{\text {th }}$, and declined of optimal nitrate on day $12^{\text {th }}$ ie $89,7 \%$. The decline value of BOD, TSS and nitrate until day $16^{\text {th }}$ has been standart quality unless TSS according to Perda Jateng no.5 tahun 2012 and PP no. 82 tahun 2001.
\end{abstract}

Corresponding Author: setiawanlara@gmail.com 


\section{INTRODUCTION}

Soybean curd industry is one of the home industry that rapidly growing in every city or country [1]. Banyumas Regency, Central Java is having 524 soybean curd industry [2].

Soybean curd waste characteristic contains organic materials and suspension solid such as BOD ranged between $3630-3650 \mathrm{mg} / \mathrm{L}$ in value, TSS $8935-13824 \mathrm{mg} / \mathrm{L}$ and $4-5$ value of $\mathrm{pH}$ [3].

The high potential of pollution due soybean curd wastewater, it is necessary to control the pollution. One of the biological methods is using artificial wetlands that are quite effective in reducing BOD, COD, TSS, NO3, sulfide, fat, and chromium levels [4].

Modification of artificial wetland with sub surface flow system using recirculation has some advantages that using plants to process wastewater (a) physical process sedimentation and filtration removal mechanism (b) physical and chemical process adsorption and phosphor and heavy metals precipitation removal mechanism (c) biochemical process degrading organic materials, nitrification, denitrification, anaerobic decomposition and absorption by water plants removal mechanism. The advantage of recirculation pattern are it can reduce TSS value to $\pm 90 \%$, and Total Nitrogen value to $50 \%$ in domestic waste treatment [5].

Based on previous wetland research using Scirpus grossus SSF system with detention time of 72 days showed the reduction of TSS value to $100 \%$ in household waste treatment [6]. Munazah and Soewondo [3] research stated that Scirpus grossus can reduce BOD value to $85,07 \%$ with 5 days contact time. The previous research result is became basis of researcher to use Scirpus with different species Schoenoplectus corymbosus (Scirpus corymbosus) in soybean curd wastewater treatment.

\section{RESEARCH METHODS}

\subsection{Research Methods and Design}

The research design used was completely randomized design (CRD) with 5 treatment: 0 day, 4 day, 8 day 12 day and 16 day contact with soybean curd wastewater and 4 replicates each treatment.

\subsection{Research Parameters}

The determinants parameter in this research was the decreasing value of Biological Oxygen Demand (BOD5), Total Suspended Solid (TSS) and nitrate $\left(\mathrm{NO}_{3}\right)$. The supporting parameters were temperature, $\mathrm{pH}$, and dissolved oxygen.

\subsection{Research Procedure}

\subsubsection{Media Preparation}

Research was started by preparing 8 container box. Container filled with $5 \mathrm{~cm}$ of medium gravel, $5 \mathrm{~cm}$ of sand, and $10 \mathrm{~cm}$ of clay then planted with $30 \mathrm{~S}$. corymbosus / container, flowed by diluted soybean curd wastewater through recirculation pipe. Modification Artificial Wetland by SSF system. 


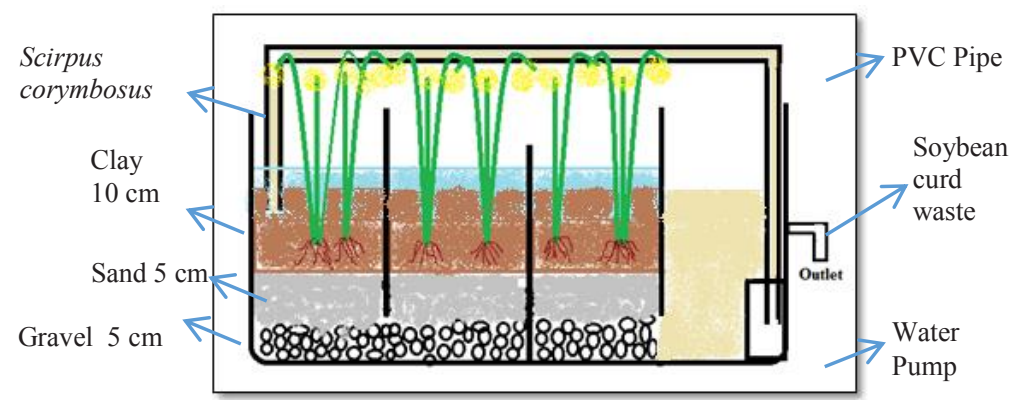

Fig 1. Wetland Modification

\subsubsection{Research Implementation}

Research implementation was divided into 4 phase:

1) Wastewater Pre-Treatment

Soybean curd wastewater taken from Kaliputih soybean industry, the wastewater was filtered, precipitated, and neutralized before it was diluted.

2) Plants Acclimatization

Chosen S.corymbosus was that growth in group. Plant was acclimated by planted it in the wetland construction to make adaptation in wetland environment.

3) Preliminary Test

Soybean curd wastewater was diluted with concentration of $50 \%$ and $75 \%$. Construction that already flowed with soybean curd wastewater was put on greenhouse for 1 week.

4) Treatment

Wetland constructions that had filled with media and plant were set. Constructions was set with a slope of $\pm 1 \%$, determinants and supporting parameters were measured for 16 days.

Table 1. Determinant Parameters Measurement

\begin{tabular}{lll}
\hline No & Parameters & Source \\
\hline 1. & BOD & {$[16]$} \\
2. & TSS & {$[16]$} \\
3. & Nitrate & {$[17]$} \\
\hline
\end{tabular}

\subsection{Research Time and Place}

The research was done in June at Plants Physiology Green House, Faculty of Biology, Jendral Soedirman University and DO and BOD5 was done at Water Quality Management Laboratory, Major of Fishery and Marine, Faculty of Science and Technique, Jendral Soedirman University. Parameters measurement such as temperature and $\mathrm{pH}$ was done in situ, and TSS and Nitrate measurement was done ex situ in Semarang Wahana Laboratory.

\subsection{Data Analysis}

Data on reduction of BOD, TSS, and Nitrate was obtained from soybean curd wastewater treatment using artificial wetland modification SSF system recirculation with $S$. corymbosus were analyzed by: 
1) Comparative descriptive to determine artificial wetland modification SSF system recirculation with S. corymbosus capability to reduce the value of BOD, TSS, and Nitrate in soybean curd wastewater.

2) F test and effectiveness level test, $F$ test was used to determine the significance of every treatment given, with $1-5 \%$ error rate. If ANOVA had showed significant difference or highly significant difference, the analysis can be progressed into Least Significance Different (LSD) test. Effectiveness of wastewater contact time with S. corymbosus to reduce the value of BOD, TSS, and $\mathrm{NO}_{3}$ measured by Effectiveness formula [15].

Keterangan :

$$
E(\%)=\frac{C o-C e}{C e} \times 100 \%
$$

$\mathrm{E}=$ Effectiveness value $(\%)$
$\mathrm{C}_{0}=$ Initial concentration $(\mathrm{mg} / \mathrm{L})$
$\mathrm{C}_{\mathrm{e}}=$ Later concentration $(\mathrm{mg} / \mathrm{L})$

3) Descriptive comparative analysis was used to compare BOD, TSS, and nitrate reduced value with standard environment quality according to Perda Jateng no.5 th 2012 dan PP no.82 th 2001 (Table 2) to measure artificial wetland type SSF with $S$. corymbosus successfulness.

Table 2. Soybean wastewater standard quality

\begin{tabular}{llll} 
& \multicolumn{3}{c}{ Table 2. Soybean wastewater standard quality } \\
\cline { 2 - 4 } & No & Parameters & Maximum Value \\
\hline 1. & Temperatur & $38^{\circ} \mathrm{C} *$ \\
2. & BOD $_{5}$ & $150 \mathrm{mg} / \mathrm{L}^{*}$ \\
3. & TSS & $100 \mathrm{mg} / \mathrm{L}^{*}$ \\
4. & pH & $6,0-9,0^{*}$ \\
5. & Nitrat & $20 \mathrm{mg} / \mathrm{L}^{* *}$ \\
6. & Debit maksimum & $20 \mathrm{~m} /$ ton kedelai * \\
\hline Exp. * Perda Jateng no.5 th 2012 & \\
** PP no.82 th 2001 &
\end{tabular}

\section{RESULT AND DISSCUSION}

\subsection{System Capability in Reducing BOD, TSS, and Nitrate Value.}

Wastewater treatment using artificial wetland affected by environmental condition such as, temperature, $\mathrm{pH}$, and dissolved oxygen because they are fundamental factor of living being. Hammer [7] stated CTW can effectively purify wastewater with same process as natural wetland consisted of plants, soil, and microbial community, but within controlled environment condition. Environment condition is optimal for wastewater treatment because it support used microorganism and aquatic plant growth, so they can reduce soybean curd wastewater BOD, TSS, and Nitrate value.

Wastewater treatment mechanism had two main focuses, first was recirculation process that happened in construction and media that its used (soil, sand, and gravel). Munazah and Soewondo [3] stated that elimination mechanism in constructed wetland were filtration and sedimentation by media, biological elimination by microorganism at soil and root. Plants accelerate the process by giving good environment for microorganism growth at ryzosphere and can transfer oxygen to root and soil so there was exchange in aerobic process (anoxic and anaerobic zone) that can make different microbes growth and eliminate pathogen [3]. 


\subsection{BOD Value Reduction}

BOD is measurement of required oxygen by aerobic microorganism to decomposing organic materials in water for five days incubated without light. Based on research result, constructed wetland capable on reducing soybean curd wastewater BOD value (Fig 2).

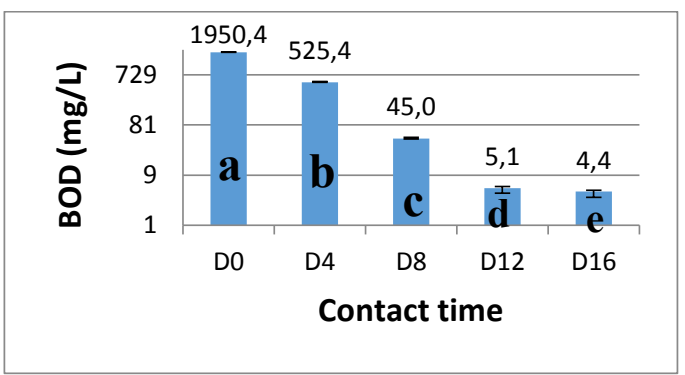

Fig 2. BOD Effectiveness Graphic

Based on picture 2, from D0 to D4 BOD value was reduced $1425 \mathrm{mg} / \mathrm{l}(59 \%)$ with effectiveness value of $73,1 \%$. Oxygen value was 0,2 so it was anaerobic process. In this condition denitrification process occur that formed nitrate converted into nitrogen gas $\left(\mathrm{NO}_{3}\right.$ $\rightarrow \mathrm{N}_{2}$ ) [8]. The nitrogen will be released and released on sediment [9].

BOD value from D0 to D8 was reduced 1905,4 mg/1 (71\%) with effectiveness value of $97,7 \%$. Longer contact time show there still reducing process from initial treatment because microorganism need time to consume organic materials, increased DO value from $5,0 \mathrm{mg} / \mathrm{L}$ to $8,0 \mathrm{mg} / \mathrm{L}$. Increased DO value made microorganism can consume more organic materials up to $97,7 \%$. Contact time from D4 to D8 made $480,4 \mathrm{mg} / \mathrm{L}$ and effectiveness $24 \%$ difference in value. This happened in 4 days because decomposition process by microorganism began to stabilized, and existing microorganism began to make contact with the waste. Munazah dan Soewondo [3] stated, biological process happened because of contact between waste and microorganism can reach $91,53 \%$ in 5 days per $4000 \mathrm{mg} / \mathrm{L}$ soybean curd waste load of influent.

BOD value from D0 to D12 was reduced $1945,3 \mathrm{mg} / 1(85,4 \%)$ with effectiveness value of $99,7 \%$. The BOD value was declined optimally because microorganism whose growth had reached stationary phase had degraded 99,7\% BOD value in soybean curd wastewater. It is allegedly in addition to the decomposition of organic materials that occur in the wetland construction system because of microorganisms in the media and microorganisms attached to the stem of the plant S.corymbosus. Stability of oxygen value of $8,0 \mathrm{mg} / \mathrm{L}$ was one of the factor that organic materials by oxidation process by microorganism was happened in the soybean curd wastewater. Contact time from D8 to D12 made $39,9 \mathrm{mg} / \mathrm{L}$ and effectiveness $40 \%$ difference in value. Wardhana [10] stated, aerobic microorganism that need oxygen in decomposing organic materials can effectively decomposing when its oxygen and nutrient needs were fulfilled.

BOD value from D0 to D16 was reduced $1946 \mathrm{mg} / \mathrm{l}$ (97\%) with effectiveness value of $98,8 \%$. It is suspected that microorganism regeneration growth activity that occur in the system is less supportive because the availability of nutrients needed for degrading organic materials were limited although oxygen availability still supportive. Contact time from D12 to D16 made $0,7 \mathrm{mg} / \mathrm{L}$ make effectiveness $0,1 \%$ difference in value. Population decline level was happened because lack of nutrient made decline in bacterial population occur, in this time dead cells is higher than living cells [11].

Based on F test, shown there was significant difference in D0, D4, D8, D12, and D16 treatment in reducing soybean curd wastewater BOD value. $\mathrm{P}<0,005$ followed by LSD test. Based on LSD test the $\mathrm{H} 0$ control treatment had a significant difference on the $\mathrm{H} 4$ contact 
time treatment, it is suspected because of the activity of microorganisms, the increased value of dissolved oxygen and $\mathrm{pH}$. The difference in treatment of D0 with $\mathrm{D} 8$ had significant response, due to the addition of longer contact time and increased in dissolved oxygen. The difference of control treatment (D0) with D12 had significant result, it is caused by microorganism performance reaching optimum point that is at stationary phase. This shows the value reached $99.7 \%$ and a decrease of $0.1 \%$ from $\mathrm{H} 12$ to H16. The longer the contact time that occurs then the process of degradation of organic pollutant parameters can take longer so that the performance of the rector will be better and the effluent concentration also decreased [3].

\subsection{TSS Value Reduction}

TSS are suspended solids that can be distinguished from their size, in example colloid suspended particles and suspended particles. The value of TSS contained in the soybean curd wastewater can be derived by the effectiveness of the system in experimental artificial wetland research with S. corymbosus plant seen in Fig 3.

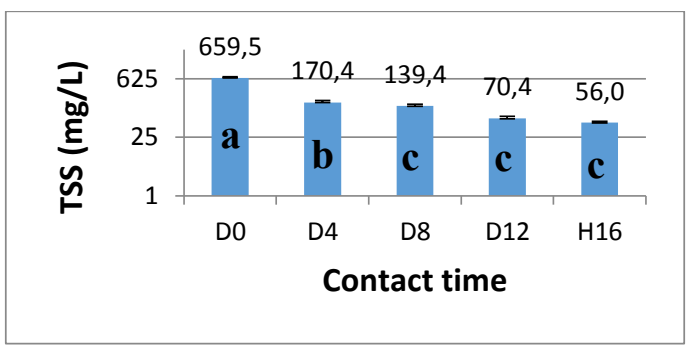

Fig 3. TSS Effectiveness Graphic

Based on picture 3, from D0 to D4 TSS value was reduced 489,2 mg/L (40\%) with effectiveness value of $74,2 \%$. It is suspected that wetland media (soil, sand, and gravel) and plants as attached places for microorganism that consume available organic materials. Slow water movement which made filtration process still unstable.

TSS value from D0 to D8 was reduced $520,1 \mathrm{mg} / 1$ (61\%) with effectiveness value of $78,9 \%$. Due 8 days wetland system condition, media, and plant began to stabilize, filtration and sedimentation process began to occur in waste. In addition, available organic materials will settle at the bottom and will get used by microorganism and inorganic materials will be released because of recirculation process and gravity. Contact time from D4 to D8 made $30,9 \mathrm{mg} / \mathrm{L}$ and effectiveness $4 \%$ difference in value. Sedimentation process occurs inside the reactor because of gravitation, while filtration process occur when particle was filtered mechanically as they pass through soil and root [12].

TSS value from D0 to D12 was reduced $589,2 \mathrm{mg} / 1(62,4 \%)$ with effectiveness value of $89,3 \%$. The TSS value was declined optimally because $89,3 \%$ TSS value in soybean curd wastewater had been degraded. This is occur because of longer contact happened between wastewater with media and plant, so with the result that filtration and sedimentation process optimally done. Contact time from D8 to D12 made $69 \mathrm{mg} / \mathrm{L}$ and effectiveness $11 \%$ difference in value. It is efficiency was increased along with detention time [13].

TSS value from D0 to D16 was reduced $603,6 \mathrm{mg} / \mathrm{L}(60,9 \%)$ with effectiveness value of $91,5 \%$. This shown that optimal reduction was happened in contact days 12, so difference in value between D12 and D16 was less significant. Contact time from D12 to D16 only $14,4 \mathrm{mg} / \mathrm{L}$ and effectiveness $2 \%$ difference in value. Prolonged detention time affect wastewater TSS reduction [12].

Based on F test, shown there was significant difference in D0, D4, D8, D12, and D16 treatment in reducing soybean curd wastewater TSS value. $\mathrm{P}<0,005$ followed by LSD test. 
Based on LSD test the H0 control treatment had a significant difference on the H4 contact time treatment due to the existence of media as a place for microorganisms to attach and water movement is still slow. Difference in treatment between control with D8, D12, and D16 gave same respond equal to the decrease in TSS value, indicated by the same letter. This is due to the longer treatment contact time will increase the efficiency of elimination process. The longer the contact time made greater sedimentation and filtration process [12].

\subsection{Nitrate Value Reduction}

Artificial wetland with $S$. corymbosus system is shown capable on reduce nitrate value in soybean curd wastewater (Fig 4)

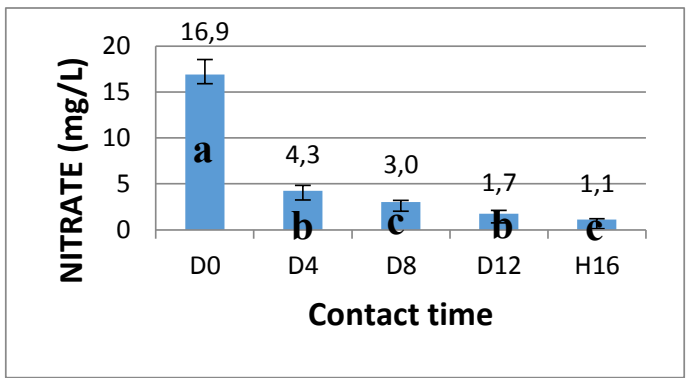

Fig 4. Nitrate Effectiveness Graphic

Based on picture 4, from D0 to D4 BOD value was reduced 12,6 mg/l (59\%) with effectiveness value of $74,8 \%$. Oxygen value was 0,2 so it was anaerobic process. In this condition denitrification process occur that formed nitrate converted into nitrogen gas $\left(\mathrm{NO}_{3}\right.$ $\rightarrow \mathrm{N}_{2}$ ) [8]. The nitrogen will be released and released on sediment [9].

Nitrate value from D0 to D8 was reduced $13,9 \mathrm{mg} / \mathrm{L}(52,6 \%)$ with effectiveness value of $82,1 \%$. This decreased in value was due the activity of bacteria with oxidized wetland system due stabilized oxygen supply which is increased to $8 \mathrm{mg} / \mathrm{L}$, so that Nitrosomonas bacteria that oxidize ammonia to nitrite and Nitrobacter that oxidize nitrite to nitrate began to work on aerobic condition. The activity of the S.corymbosus plant is getting stronger by utilizing the nitrate produced from the nitrification process. Contact time from D4 to D8 made $1,3 \mathrm{mg} / \mathrm{L}$ make effectiveness $8 \%$ difference in value. This aerobic condition triggers nitrification process, ammonium nitrogen converted to nitrate $\left(\mathrm{NH}_{4}+\rightarrow \mathrm{NO}_{3}\right)$ [8].

Nitrate value from D0 to D12 was reduced $15,2 \mathrm{mg} / \mathrm{L}(66,2 \%)$ with effectiveness value of $89,3 \%$. The nitrate value was declined optimally because good media and stable supply of oxygen. The absorption of nitrogen by S.corymbosus stem, allows microorganisms growth around the stem. Contact time from D8 to D12 made $1,31 \mathrm{mg} / \mathrm{L}$ and effectiveness $7 \%$ difference in value. Nitrogen will be taken by plants in mineral form and became plant biomass [9] and plants use nitrate and ammonium as nutrition that can be stored in inorganic nitrogen form.

Nitrate value from D0 to D16 was reduced $15,8 \mathrm{mg} / \mathrm{L}(\%)$ with effectiveness value of $93,5 \%$. It is suspected to occur because available nutrient was used in 12 days of contact and optimally used. Contact time from D12 to D16 made $0,6 \mathrm{mg} / \mathrm{L}$ make effectiveness $4 \%$ difference in value.

Based on $F$ test using minitab version 16 software, shown there was significant difference in D0, D4, D8, D12, and D16 treatment in reducing soybean curd wastewater nitrate value. $\mathrm{P}<0,5$ followed by LSD test. Based on LSD test shown D0 to D4 and D12 contact time treatments provide the same response, indicated by the same letter, as well as on the treatment of contact times D8 and D16. The control treatment D0 gave a real 
response to the treatment of contact time D4 and D12 due to denitrification and nitrification process. Control D0 treatment shown significant response to D8 and D16. That is because the condition of wetland system and oxygen supply had been stabilized

\subsection{CTW Processed Quality Standard}

Based on research result of soybean curd wastewater treatment using sub surface flow system with S.corymbosus can reduce BOD value at 16 days contact time with average value of $58,8 \mathrm{mg} / \mathrm{L}$, the value met the quality standard because the value was $<150 \mathrm{mg} / \mathrm{L}$ [18]. TSS reduce in value until 16 days of contact time with average value if $267,9 \mathrm{mg} / \mathrm{L}$, the value did not meet the quality standard because the value was $>100 \mathrm{mg} / \mathrm{L} \mathrm{[18]}$. Nitrate reduce in value until 16 days of contact time with average value if $5,7 \mathrm{mg} / \mathrm{L}$, the value met the quality standard because the value was $<20 \mathrm{mg} / \mathrm{L}$ (PP no.82 th 2001).

\section{CONCLUSIONS}

Modified artificial wetland using sub surface flow system can reduce BOD, TSS, and nitrate value in soybean cur wastewater. Most optimal contact time for reducing BOD, TSS, and nitrate value by was at the $12^{\text {th }}$ day each $99,7 \%$ : $89,3 \%$; and $89,7 \%$. BOD and nitrate reduced value met with quality standard except for TSS. Based on research result, impact of contact time between modified artificial wetland using SSF system with S. corymbosus in soybean curd wastewater treatment do not use fish as experimental animal, so the need for further research to determine the effect of modified artificial wetland used.

\section{REFERENCES}

1 Jasmiati., Sofia, A. Journal of Enviromental Science. 2 (2010)

2 Dinas Perindustrian Perdagangan dan Koperasi Kabupaten Banyumas. 2014. Diakses tanggal 23 Oktober 2014.

3 Munazah, A. R. dan Soewondo, P. 4, 1-8 (2008)

4 Ningsih, D. Martianto, T., Harjanto, S. Pemanfaatan Air Olahan Wetland di Sitimulyo dalam Pembuatan Pikel Kulit Domba. 28, (2012)

5 Prigent, S., Paing, J., Andres, Y., dan Chazarenc, F. Effects of a saturated layer and recirculation on nitrogen treatment performances of a single stage Vertical Flow Constructed Wetland (VFCW). Water Science \& Technology. 68,7 (2013)

6 Al-Badawi, I.A., Abdullah, S.R.S., Anuar, N., Suja, F., Idris, M.. Water Science \& Technology. 68.10.

7 Hammer. Constructed Wetland for Wastewater Treatment: Municipal, Industrial and Agricultural. (Chelsea : Lewis Publisher, 1989)

8 Hastuti, E., dan Agustien, R.R. 8, (2013)

9 Wetland International. 2003. The use of constructed wetlands for wastewater treatment. Malaysia Office. 24 pp.

10 Wardhana, W.A. Dampak Pencemaran Lingkungan. (Penerbit Andi Yogyakarta, 2004)

11 Brock, T.D. and Madigan, M.T. Biology of Microorganism. (Prentice Hal International Inc, Englewos Clifs, New Jersey, 1991) 
12 Masturah, A., Darmayanti, L., Lilis Y. Pengolahan Air Limbah Domestik Menggunakan Tanaman Alisma plantago dalam Sistem Lahan basah Buatan aliran Bawah Permukaan. (Pekanbaru, Riau, 2014)

13 Abdulgani, H., Izzati, M., Sudarno. Semnas Pengelolaan Sumberdaya Alam dan Lingkungan (2013)

15 Kasam., Yulianto, A., Sukma, T. Logika. 2, 3-16 (2005)

16 APHA, AWWA, AWEF. Standard Methods for The Examination of Water and Wastewater . (Washington. 2005

17 SNI 06-2480. Cara Uji nitrat $\left(\mathrm{NO}_{3}-\mathrm{N}\right)$ dengan Spektofotometer UV-Visible. (Badan Standarisasi Nasional, 1991)

18 Perda Jateng No.5 Tahun Peraturan Daerah Jawa Tengah No.5 tahun 2012 Tentang Baku Mutu Limbah Cair Tahu. (2012) 